\title{
SOME OBSERVATIONS ON A RECENT SURGE OF PETERS GLACIER, ALASKA, U.S.A.
}

\author{
By Keith EChelmeyer, \\ (Geophysical Institute, University of Alaska-Fairbanks, Fairbanks, Alaska 99775-0800, U.S.A.) \\ Robert Butterfield, and Doug Cuillard \\ (Denali National Park, Denali, Alaska 99755, U.S.A.)
}

ABstract. A spectacular surge occurred on Peters Glacier, Alaska, in 1986 and 1987. Several observations on the glacier were made during the course of its surge. These observations are compared with those on other surging glaciers and then interpreted in terms of the ideas on surge mechanisms and dynamics as originally postulated by Post (unpublished) and further developed during the surge of Variegated Glacier by Kamb and others (1985) and Raymond and Harrison (1986, in press). It is shown that the concepts of rapid basal motion due to high water pressure at the glacier bed and the initiation of a surge during the winter due to a pressurization of the limited supply of basal water are well supported by these observations on the surge of Peters Glacier. An extremely high suspended sediment load rich in very fine material was observed, which also supports ideas on basal processes expected during this type of surge.

One interesting (and puzzling) feature of this surge cycle is that the termination of the surge occurred in late winter 1987, when surface melt water was at a minimum. This is in direct contrast to the termination of the surge on Variegated Glacier, which occurred during the period of peak ablation.

\section{INTRODUCTION}

Observations of glaciers during an active phase of surging are of limited extent, but are critical to the development and testing of theories on surge mechanisms and surge dynamics. Based on aerial observations of several glaciers in surge, Post (unpublished) developed ideas on the role of high-pressure water at the glacier bed in causing rapid sliding during a surge. The detailed observations of Dolgoushin and Osipova (1973) on Medvezhy Glacier; Bindschadler and others (1977), Kamb and others (1985), and Raymond and Harrison (1986, in press) on Variegated Glacier, and Clarke and others (1984) on the pre-surge phase of Trapridge Glacier, have each led to separate theoretical ideas on how and when surges are initiated, the dynamics of their propagation, and the reason for termination. Other theoretical ideas on surge-front propagation have been developed by McMeeking and Johnson (1986). In order to understand fully the surge phenomenon in its generality, the ideas developed in these studies must be tested using data derived from measurements on other glacier surges. The spectacular surge of Peters Glacier, Alaska, from 1986 to 1987 provides such an opportunity.

In the present note we present observations of Peters Glacier made by various helpful groups during its surge. These observations, while much less quantitative and less detailed than those on Variegated and Medvezhy Glaciers during surge, offer direct comparison with features of these other surges and help illuminate the actual mechanics of the surge phenomenon.

\section{GEOGRAPHICAL SETTING AND GLACIER GEOMETRY}

Peters Glacier is situated along the northern side of Mount McKinley $(6194 \mathrm{~m})$, flowing in a north-north-western direction from an elevation of $3810 \mathrm{~m}$ to a terminus at an elevation of about $920 \mathrm{~m}$, with tributaries extending up to an elevation of $5934 \mathrm{~m}$ (Fig. 1). The glacier is approximately $27 \mathrm{~km}$ long, 1-2 km wide along the valley, and encompasses an area of about $120 \mathrm{~km}^{2}$ (Field, 1975) the surface has a mean surface slope of approximately $3.5^{\circ}$ along its length below Tluna Icefall. The location of the glacier places it in a continental-type climatic zone typical of interior Alaska - cold, dry winters and moderate summers. Accumulation in the upper reaches of the glacier is estimated to be approximately $1 \mathrm{~m}$ water equivalent per year based on balance measurements made $100 \mathrm{~km}$ to the east (personal communication from $T$. Clarke) and the equilibrium-line altitude is approximately $1800 \mathrm{~m}$. Melt water from this glacier basin forms the Muddy River.

This glacier is one of several large surging glaciers located along the tectonically active Denali fault zone (others include Muldrow, Susitna, Black Rapids, Yanert, Foraker, and Straightaway Glaciers; Post, 1969; paper in preparation by S. Wilbur and A. Post). The sharp right-angled bend in the valley of Peters Glacier (and Muldrow Glacier) is probably associated with the Denali fault. The bedrock beneath the glacier (below the ice fall) is generally a friable, low-grade metamorphic rock type and not the massive plutonic bedrock found on the south of the range. The fault-generated geometry and "weak" bedrock type may possibly be correlated with the large number of surging glaciers in this region.

The morainal patterns of Peters Glacier indicate that previous surges have occurred (Post, 1969). R. Priebe (personal communication) estimated the timing of the last surge in the early $1890 \mathrm{~s}$ based on photographs and dendrochronology. Surges have occurred on nearby glaciers in the historical past, such as Muldrow Glacier, 1956-57 (Harrison, 1964); Yanert Glacier, 1942 (Post, 1960); and Straightaway Glacier, 1983 (personal communication from R. Priebe).

\section{OBSERVATIONS ON THE HISTORY OF THE SURGE}

Although no continuous monitoring program was carried out during the surge, Peters Glacier was visited and observed by several different persons during the active surge period and many features of this surge can be determined from these observations, including approximate propagation speeds and the timing of various surge-related events.

The first indication that the glacier was in other than a steady state was in mid-April 1986. A group of skiers were descending Peters Glacier and reported extreme difficulty in crossing back on to the glacier just below Tluna Icefall along the usual route. A large "pressure ridge" and highly crevassed region along the western margin extended from the base of the ice fall down-glacier $1 \mathrm{~km}$ 


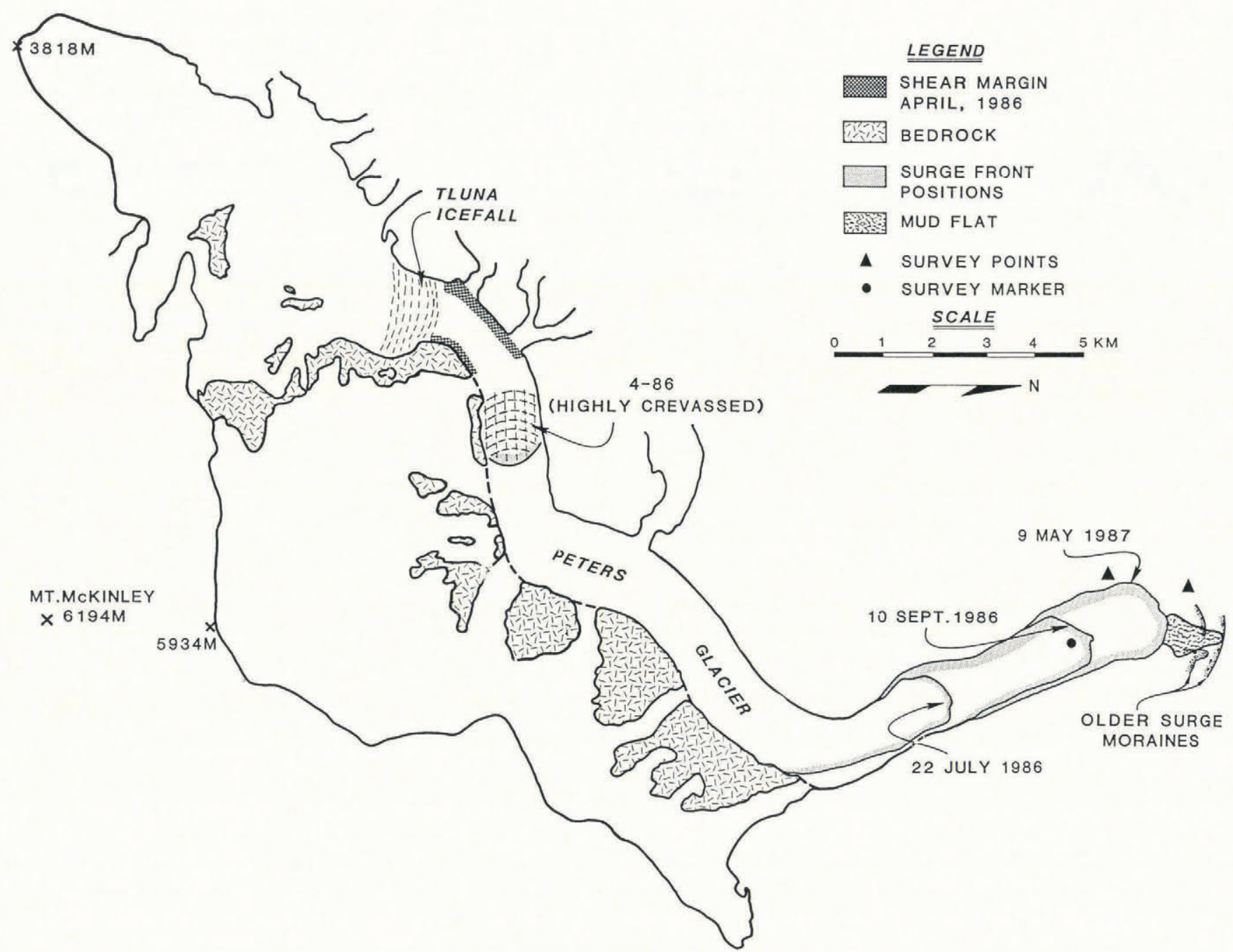

Fig. 1. Map of Peters Glacier showing position of the surge front at different times, the plain of fine sediment observed in May 1987, and older surge moraines.

or more (personal communication from J. Neuspiel). This was the shear zone at the margin associated with surge-type motion on the upper glacier; the "pressure ridge" was similar to the ridge of seracs found along upper Variegated Glacier during the earlier part of that surge. This marginal shear zone did not exist below Tluna Icefall in previous years. After crossing this zone and while traveling down the center of the glacier, this group encountered a freshly crevassed zone, with numerous intersecting longitudinal and transverse crevasses. This zone was approximately $2 \mathrm{~km}$ in length and extended to a point $3 \frac{1}{2} \mathrm{~km}$ below the base of the ice fall, where there (possibly) was a relatively steep drop down to the relatively uncrevassed glacier down-valley. Previous to this time, the glacier was relatively smooth below the ice fall, with only a few transverse crevasses appearing late in the ablation season. What this group of skiers had encountered was the bulge at the surge front and the region of intense crevassing behind the front, causing many a fall through fragile snow bridges.

On 26 May 1986, C. and N. Bale were crossing the Muddy River, as they had done at the same time of year for a dozen years previously. The river stage was abnormally high and the water exceptionally turbid, requiring a search for an ice bridge across the flooding torrent. This flood indicates that the surge was well in progress by May, with a large discharge of stored water occurring during the surge.

A photograph taken by S. Lewis, Camp Denali, during an observation flight on 22 July shows a well-developed surge front in moraine-covered ice just below the distinct right-angle bend of the glacier (Fig. 1). In August, the glacier appeared into view for the first time from Wonder Lake, $25 \mathrm{~km}$ to the north.

During early September, a group from Denali National Park Service camped near the advancing surge front. Highly turbid water samples were collected from streams which were observed to flood and to change their exit point beneath and within the surge front on a short time-scale. The surge front was observed to advance into a longitudinal line of pre-placed cairns along the moraine at a rate of $24 \mathrm{~m} / \mathrm{d}$.

Photographs taken by the authors in early to midSeptember show several interesting features of the surge, including: (1) a well-developed, debris-rich shear margin along the length of the glacier from below Tluna Icefall to the terminus; (2) several tributary glaciers left behind by the surge; (3) a draw-down of the ice surface amounting to approximately $70 \mathrm{~m}$ in the upper reaches of the glacier affected by the surge; (4) the accumulation region above Tluna Icefall was unaffected by the surge; (5) several lakes containing turbid water at the margins and in large crevasses along the glacier; (6) several turbid streams emanating from within the surge front; and (7) large furrows $(50+m$ deep) and regions of blocky seracs in the broken glacier surface, showing signs of significant inflation behind the surge front.

On 18 and 19 March 1987, a group of climbers camped at the terminus of the glacier (personal communication from B. Okonek). They observed that the surge front was not active and that there was little buckling of recent snow in front of the glacier (such buckling would be expected if the front were advancing). The river level 
also appeared to be dropping at this time but the water was still highly turbid.

Survey measurements made on 9-10 May 1987, of a marker on the ice $2 \mathrm{~km}$ up-glacier from the terminus, indicated a velocity of $11 \mathrm{~cm} / \mathrm{d}$, well below surge speeds. The surface of the moraine-covered ice on the lower glacier was inflated $120 \mathrm{~m}$ above its pre-surge level. The terminus was not active during this time (or at the end of May, as well; personal communication from N.P.S.), there was no buckling of snow in front of the terminus, and the river was low and not highly turbid.

The surge front had propagated into morainal material which supported medium-sized willows, but did not propagate as far as at least two older surge moraines observed about $1 \mathrm{~km}$ down-valley. Thus, the surge was probably stronger than the most recent previous surge, but somewhat weaker than two others occurring in the past.

The surge had clearly terminated before May and, by all indications, had stopped in or before early March.

A large "mud flat" was observed adjacent to the terminus of the glacier in May 1987 (Fig. 1). This plain was composed of a thick (up to $0.4 \mathrm{~m}$ ) accumulation of very fine glacial flour (clay and silt); in some places it was deposited above ice-covered glacier streams. There existed a "bath-tub ring" approximately $0.5-0.75 \mathrm{~m}$ above the mud plain around its periphery, indicating that a lake or layer of water-saturated snow and ice had existed here sometime earlier. A coating of this fine glacial flour covered the Muddy River channel nearly $15 \mathrm{~km}$ down-valley, almost to its confluence with the McKinley River system. From the nature of this deposit and its extent, we postulate that a large outburst flood from the glacier occurred during the winter (pre-dating late March), possibly soaking the overlying snow and forming a very sediment-rich layer of overflow ice adjacent to and down-stream of the surge front.

This large flood may have coincided with the surge termination, as was observed on Variegated Glacier. However, no actual indications of a rapid flow of large quantities of water, such as large ripple-marks and superelevated high-water marks on up-stream-facing hillocks or bends, were observed, so it is not known how quickly the deposit was formed.

From these observations we see that the surge started sometime before 18 April 1986. We estimate that the surge started as early as 1 February based on a propagation speed of $50-100 \mathrm{~m} / \mathrm{d}$ (see below). However, it may have started at an even earlier date if the propagation were slower near the time of initiation. The average speed of propagation from April to 22 July was $110 \mathrm{~m} / \mathrm{d}$. From 22 July to 5 September, the propagation speed was $54 \mathrm{~m} / \mathrm{d}$ and was measured to be $24 \mathrm{~m} / \mathrm{d}$ in mid-September. Over the $1986-87$ winter the surge front moved at a speed of approximately $11-15 \mathrm{~m} / \mathrm{d}$, assuming a surge termination date in early March. This reduction in propagation speed may, in part, be explained by the increase in width of the valley walls and of the terminal lobe which occur below the bend.

The amount of suspended sediment in two samples obtained from one of the turbid outlet streams during September 1986 was $35-50 \mathrm{~g} / \mathrm{l}$, which is much larger than commonly observed in glacier streams. Post-surge (May 1987) water samples contained approximately $1.7 \mathrm{~g} / 1$, more in keeping with "normal" glacier outflow (Humphrey, unpublished). The distribution of particle size in the surge samples is shown in Figure 2. There is a much larger proportion of very fine sediment in the suspended load than found in the suspended load of "normal" glacier streams.

\section{COMPARISON WITH OTHER SURGES AND IDEAS ON} SURGE DYNAMICS

Many of the observations on the surge of Peters Glacier may be compared directly with detailed measurements made on Variegated Glacier during its 1982-83 surge (all references to Kamb and others, 1985) and on Medvezhy Glacier in the U.S.S.R. (all references to Dolgoushin and Osipova, 1973), and with qualitative observations made elsewhere (in particular by Post

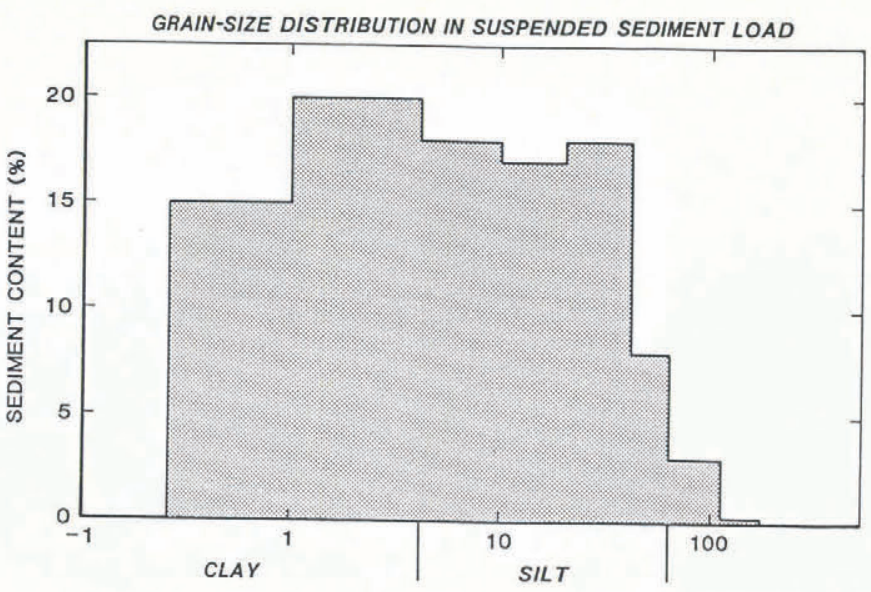

GRAIN-SIZE $(\mu \mathrm{m})$

Fig. 2. Particle-size analysis of suspended sediment contained in a water sample collected from a stream emanating from the surge front in early September 1986. Total suspended sediment load in this sample was 50 g/l.

(unpublished)). Such comparison then allows various aspects of the theory of glacier surging to be tested.

We first discuss the changes in geometry which occurred during the surge. This is then followed by a discussion of the hydrologic conditions associated with the surge.

The presence of a sharp, debris-laden shear margin indicates that transverse plug flow was present, as was observed on Variegated and Medvezhy Glaciers. The debris may come from the bed, and its presence along the shear zone may aid in the development of the sharp velocity discontinuity across the thin zone. Such a shear zone may also be indicative of a predominant contribution of basal sliding to surge motion.

The mixed longitudinal and transverse crevassing behind the propagating surge front indicates a changing stress field, with a strong compression as the front arrives and extension as it passes, as described in the model calculations by McMeeking and Johnson (1986) and T. Pfeffer (personal communication). On the lower glacier, the ice is inflated upon arrival of the surge front, with a large rise in surface elevation and the development of a characteristic serac and crevasse pattern. Long longitudinal furrows occur which are often much deeper than normal crevassing due to the large tensile stresses accompanying the inflation. The surface shown in Figure 3 is characteristic of a glacier during surge.

The rapid advance of the surge front $(50-110 \mathrm{~m} / \mathrm{d})$ is typical of surge propagation as measured on Medvezhy, Variegated, and Muldrow Glaciers. (The surge on Muldrow Glacier appeared to propagate at faster rates - up to $350 \mathrm{~m} / \mathrm{d}$ - at some locations (Harrison, 1964).) This rate of propagation is that required by mass continuity given an ice speed and ice thickness, being the front which is determined by surge mechanics. A draw-down in the upper reaches of the glacier below the ice fall (the reservoir) of $50-70 \mathrm{~m}$ and a thickening of nearly $120 \mathrm{~m}$ of the lower (receiving) end of the glacier agrees well with that observed on Variegated and Medvezhy Glaciers - perhaps this is indicative of the changes in basal shear stress and normal stress required for surge initiation on a temperate glacier (in a manner proposed by Raymond and Harrison (in press)).

The evidence from Peters Glacier indicates that the surge may have started in mid-winter and is therefore consistent with the wintertime surge-initiation mechanism described by Raymond and Harrison (1986) for Variegated Glacier. However, this surge of Peters Glacier may also have started at some earlier time in 1985 if the surge front initially propagated at a much slower rate than was used in our approximation.

The other major parameter for comparison is the subglacial water and associated sediment load. The presence of 


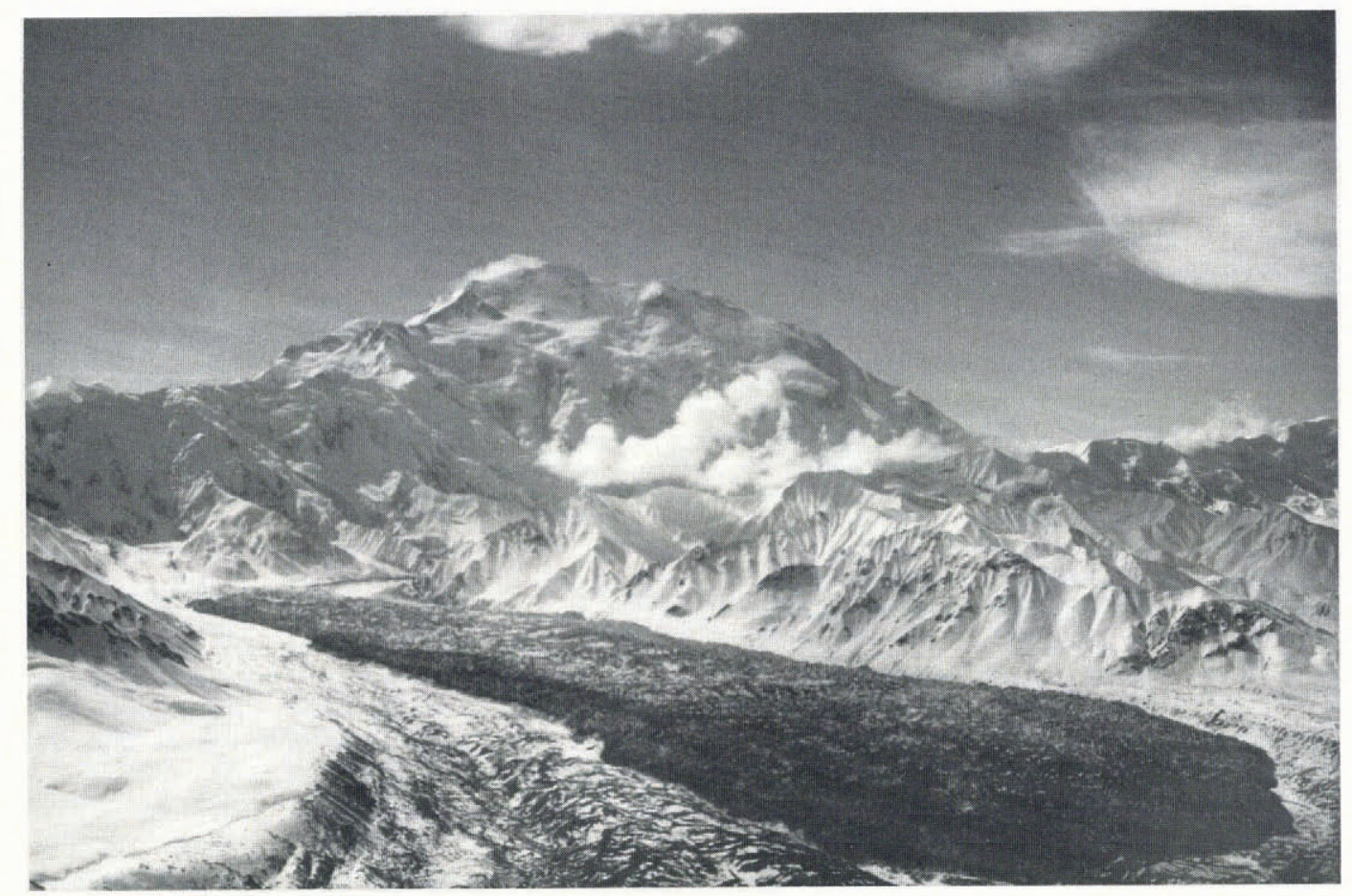

Fig. 3. Photograph of Peters Glacier during its surge, showing surface morphology, zones of marginal shear, and advancing surge front. Mount McKinley $(6194 \mathrm{~m})$ is in the background. (Photograph taken mid-September 1986 by C.A. Peterson.)

supraglacial and marginal lakes of turbid water point to a subglacial source and, thus, basal water pressures which are close to those required effectively to "float" the glacier and promote very rapid sliding. Such high pressures were measured on Variegated Glacier during surge (Kamb and others, 1985), and these high pressures, along with the formation of supraglacial lakes, were highly correlated with the rapid ice motion during the history of that surge. Outburst floods of extremely turbid water through various exit portals in the surge front were observed during the surge on Variegated Glacier (Brugman, unpublished; Humphrey, unpublished) and these floods corresponded to major fluctuations in ice motion up-glacier of the surge front. The large flood observed on Muddy River by C. and N. Bale in May 1986 was probably associated with such an outburst flood on Peters Glacier.

The presence of a large "mud plain" as a possible flood deposit and its relation to the probable time of surge termination (it is likely that the deposit formed in winter or early spring) is consistent with the observed surge termination on Variegated Glacier (Humphrey, unpublished). (A similar debris-charged flood was observed on Variegated Glacier in early February 1983. This flood was accompanied by a major slow-down in glacier speed as observed by automatic camera (Kamb and others, 1985).) On that glacier, a major flood of highly sediment-charged water emanated along the surge front at the time of surge termination. A drop of the glacier surface accompanied that flood and the magnitude of the drop is comparable to that expected from the closure of basal and intraglacial cavities which could have produced the flood waters.

The high sediment content of the glacier stream during surge and a much smaller load in the post-surge stream were also found on Variegated Glacier by Humphrey (unpublished) and Brugman (unpublished). These authors associated the large change in sediment content with a change in the type of drainage system ("linked-cavity" or "tesselated" system to flow in a few large conduits) and a large decrease in erosion at the bed associated with the drop in sliding speed or bed-deformation rate. Similarly, the anomalously high proportion of clay- and silt-sized particles in the sediment load observed during the surge is comparable to that observed by Humphrey (unpublished) and Brugman (unpublished) on Variegated Glacier. These authors attributed the high proportion of fines to the storage of coarser sediments which settle quickly in the slow-moving basal water occurring during the surge.

\section{CONCLUSIONS}

From the above discussion we see that the surge of Peters Glacier is consistent with a mechanism of surge initiation and propagation as developed by Post (unpublished), Kamb and others (1985), Raymond and Harrison (1986), and Raymond and Harrison (in press) - namely, the development of high subglacial water pressure in a distributed system of basal water flow which begins under a somewhat over-steepened and over-thickened glacier (in the upper reaches) during the season of low surface-water input. The high water pressures then lead to very rapid sliding or rapid deformation of a saturated debris-laden substratum.

An intriguing and puzzling question remains, however. The surge on Variegated Glacier terminated within a few days of the time when the surface snow-pack became soaked with melt water and isothermal at and below the equilibrium line (approximately) during the melt season (as observed by one of the present authors (K.E.)). A change in the subglacial drainage system (Brugman, unpublished) and a drop in basal water pressure accompanied the rapid input of surface melt which, presumably, the surface snowpack could no longer buffer by storage. A similar, yet temporary, cessation occurred in the summer of 1982 on Variegated Glacier. Such a change in the snow-pack on Peters Glacier during a period of rapid ablation must have occurred during the summer of 1986, and yet the surge did not terminate. Instead, the surge continued to propagate at a high speed through the summer, into the autumn, and probably into the winter, possibly terminating only when the up-glacier reservoir of ice was expended. Why was this the case? How do the basal drainage systems and bed morphologies of these two glaciers differ? One possibility is 
that basal conditions are much different on Peters Glacier than on Variegated Glacier, with sediment possibly restricting the water flux in the links between cavities providing a greater damming action, allowing the surge to continue through the summer and winter. Or, a till-like layer at the bed may be much slower to respond to internal water input and serve to extend the surge.

One may well have to wait for the next surge of Peters Glacier to answer these specific questions. Based on the observed draw-down of the upper glacier and net mass balance there, one may have to wait a half-century or more $\left(50-70 \mathrm{~m} \div 1 \mathrm{~m} \mathrm{a}^{-1}\right)$ !

\section{ACKNOWLEDGEMENTS}

This note is largely based on the reports of several interested observers, to whom we express our gratitude. Those people include J. Neuspiel, R. Priebe, B. Okonek; C. and N. Bale, S. Lewis, R. and G. Pederson, and W. Cole of Camp Denali; and J. Anderson, L. Davis, J. Pascale, and A. Smith from Denali National Park. We are also grateful to T. Clarke for the stream-sample analyses and W. Harrison, K. Hutter, and A. Post for helpful comments on the manuscript.

\section{REFERENCES}

Bindschadler, R., and others. 1977. Geometry and dynamics of a surge-type glacier, by R. Bindschadler, W.D. Harrison, C.F. Raymond, and R. Crosson. Journal of Glaciology, Vol. 18, No. 79, p. 181-94.

Brugman, M.M. Unpublished. Water flow at the base of a surging glacier. [Ph.D. Dissertation, California Institute of Technology, 1986.]

Clarke, G.K.C., and others. 1984. Flow, thermal structure, and subglacial conditions of a surge-type glacier, by G.K.C. Clarke, S.G. Collins, and D.E. Thompson. Canadian Journal of Earth Sciences, Vol. 21, No. 2, p. 232-40.
Dolgushin, L.D., and Osipova, G.B. 1973. Regime of a surging glacier between advances. (In [International Hydrological Decade.] The Role of Snow and Ice in Hydrology. Proceedings of the Banff symposia, September 1972. A contribution to the International Hydrological Decade. Paris, UNESCO; Geneva, WMO; Budapest, IAHS, Vol. 2, p. 1150-59. (Publication No. 107 de l'Association Internationale d'Hydrologie Scientifique.))

Field, W.O., ed. 1975. Mountain glaciers of the northern hemisphere. Vol. 2. Hanover, NH, CRREL.

Harrison, A.E. 1964. Ice surges on Muldrow Glacier, Alaska. Journal of Glacio!ogy, Vol. 5, No. 39, p. 365-68.

Humphrey, N.F. Unpublished. Basal hydrology of a surge-type glacier: observations and theory relating to Variegated Glacier. [Ph.D. Dissertation, University of Washington, 1987.]

Kamb, B., and others. 1985. Glacier surge mechanism: 1982-83 surge of Variegated Glacier, Alaska, by B. Kamb [and 7 others]. Science, Vol. 227, No. 4686, p. 469-79.

McMeeking, R.M., and Johnson, R.E. 1986. On the mechanics of surging glaciers. Journal of Glaciology, Vol. 32, No. 110, p. 120-32.

Post, A.S. 1960. The exceptional advances of the Muldrow, Black Rapids, and Susitna glaciers. Journal of Geophysical Research, Vol. 65, No. 11, p. 3703-12.

Post, A. 1969. Distribution of surging glaciers in western North America. Journal of Glaciology, Vol. 8, No. 53, p. 229-40.

Post, A. Unpublished. Water buoyancy: possible cause of high flow rates in surging glaciers. [Unpublished manuscript 1968.]

Raymond, C.F., and Harrison, W.D. 1986. Winter initiation of surges. (In Hydraulic Effects at Glacier Bed - an International Workshop. Proceedings. Zürich, Eidgenössische Technische Hochschule. Versuchsanstalt für Wasserbau, Hydrologie und Glaziologie. [Abstract.] (ETH-VAW Publication 90.))

Raymond, C.F., and Harrison, W.D. In press. Progressive changes in geometry and velocity of Variegated Glacier, Alaska, U.S.A., prior to surge. Journal of Glaciology. 